\title{
EMERGING VISIONS OF ANOTHER WORLD? TENSIONS AND COLLABORATION AT THE QUEBEC SOCIAL FORUM
}

\author{
Pascale Dufour \\ Department of Political Science \\ University of Montreal \\ pascale.dufour@umontreal.ca \\ Janet Conway \\ Department of Sociology \\ Brock University \\ jconway@brocku.ca
}

\begin{abstract}
The Quebec Social Forum (QSF) took place 23-26 August 2007 in Montreal. It attracted about 5000 people from across Quebec. Both organizers and observers viewed the event as an unqualified success. In this article, we seek to describe and document this historic gathering and to understand it in its Quebec context, against the larger organizing process which produced it. We also situate the Social Forum, both as event and process, within the longer history of social mobilization in Quebec. Historicizing the Social Forum in this way helps us interpret its cleavages and conflicts more adequately and apprehend its larger significance. We argue that the conflicts that have plagued the organizing of the Quebec Social Forum are a reprise of those that appeared in the movement in the late 1990s and came to a head in the 2001 massive demonstrations against the Free Trade Agreement of the Americas in Quebec City. The chasm then was widely perceived as one over tactics but we argue, then and now, it is more substantive than that. It is about the clash of profoundly different ethics, practices and theories of democracy and, beneath them, different horizons of hope and visions of transformation. The organizing of the Social Forum is the occasion for this debate, which may say something about the significance of the Social Forum more generally and the challenge it poses to established cultures and practices of politics on the left. The cleavage is generational but not only or simply. It signals a struggle and transition but the outcomes are not yet clear and are certainly not pre-ordained.
\end{abstract}

\section{INTRODUCTION}

The Quebec Social Forum (QSF) took place 23-26 August 2007 in Montreal on the campus of Université du Québec à Montréal (UQAM). It attracted about 5000 people from across Quebec 
around the slogan, "It's our turn to think another Quebec" in the largest assembly of progressives in Quebec's history. Both organizers and observers viewed the event as an unqualified success.

In this article, we seek to describe and document this historic gathering and to understand it in its Quebec context, against the larger organizing process which produced it. We also wish to situate the Social Forum, both as event and process, within the longer history of social mobilization in Quebec, especially under the rubric of the 'alter-globalization' movement ${ }^{1}$. Historicizing the Social Forum in this way helps us interpret its tensions more adequately and apprehend its larger significance. We are interested in reading the Quebec Social Forum for what it tells us about collective actors in Quebec, their present orientations, capacities, limitations, and conflicts, as well as their contributions to the global movement against neoliberal globalization, one crystallization of which is the world-wide social forum process. We also think the Quebec Social Forum helps us perceive the contours of a politico-cultural struggle and transition in social movement politics that has been underway in Quebec for the last decade and that we suspect is also symptomatic of seismic shifts in the nature of politics more globally that the appearance of the World Social Forum augurs.

Boaventura de Sousa Santos (2006) argues that our time is one of paradigmatic transition in which the hegemony of the socio-cultural paradigm of western modernity is being displaced. He suggests that the appearance of the World Social Forum is both a symptom and a response to that condition. One aspect of the transition is the deep crisis in left politics, in both theory and practice, and the tensions manifest between that emancipatory tradition and the newness represented by the World Social Forum. He identifies two facets of its newness that make it disturbing for the left. First, the social forum as a political form represents a break with the disciplines of modern political organization, be it based on representative democracy, democratic centralism or participatory democracy. Second, the World Social Forum is utopian in a world devoid of utopia and to a left which has lost hope in utopia. We think that the struggles over the Quebec Social Forum bear this out. Thus this is an empirical exploration of the claims that Santos is advancing in a global and highly abstracted way, grounded in the study of a particular placebased social forum process.

At a roundtable organized at the Université de Montréal on October 12, about six weeks following the event and involving some of the key actors, somewhat overlapping but also conflicting visions of the Social Forum were clearly manifested, expressing tensions persistent in the organizing process and running deeply through the history of the alter-globalization movement in Quebec. For Raphaël Canet (2007a), member of the Secretariat of the QSF and of the student group Alter-UQAM, the QSF was an opportunity to create spaces of encounter among activists, especially between those in organized social movements and ordinary citizens who share concerns about collective well-being. The Forum could certainly help facilitate the convergence of struggles of the organizations present but, he said, "it is not the QSF which will change things but those who participate in it." From this perspective, what is primary is the creation of a pre-figurative space, conceived of as both event and process, that is the most inclusive and horizontal possible in which both unaffiliated individuals [les citoyen(ne)s] and activists articulated to movements and organizations [les militant(e)s] find their place.

\footnotetext{
${ }^{1}$ The term 'alter-globalization' highlights the search for an alternative form of globalization and is preferred in some quarters to 'anti-globalization' as a way of describing the movement of movements against neo-liberalism.
} 


\section{JOURNAL OF WORLD-SYSTEMS RESEARCH}

For Jacques Létourneau (2005), in charge of international relations for the Confédération des Syndicats Nationaux (CSN), it is the formally-constituted organizations of civil society and particularly labor unions which are in the forefront of contesting globalization. Thus, "in 2001, at the People's Summit it was us, the labor centrals, who mobilized... the Quebec Summit, it was us.” Accordingly, the QSF could not have happened, could not have been imagined or put in place, without the "large organizations" (read: unions and big NGOs). Their material support underwrote the process and their constituencies expected accountability. In the organizing process, they were not prepared (because they were constrained by their positions as unions) to grant decision-making voice to unaffiliated activists. The CSN views the QSF event as an open space, quite apart from the organizing process that produced it. The organizing, in fact, demanded a more hierarchical structure with those in the leadership clearly designated and mandated. For them, political assessment of the value of the QSF would be determined by the concrete actions and outcomes, not those that are taken in the name of the QSF, but that flow from the event, not in the praxis of organizing it, nor in the quality of the event itself.

We argue that these two different and sometimes concurrent visions of what the QSF should be have resulted in tensions that have characterized the organizing of the Quebec Social Forum and which are evident in the two perspectives expressed above. We also argue that these tensions are a remix (or a new expression of/or linked with) of those that appeared in the movement in the late 1990s and came to a head in the 2001 demonstrations against the Free Trade Agreement of the Americas in Quebec City. The dispute then was widely perceived as one over tactics but we argue, then and now, it is more substantive than that.It is about the encounter between two profoundly different sets of ethics, practices and theories of democracy reflecting different horizons of hope and visions of transformation. The organizing of the Social Forum is the occasion for this debate, which says something about the significance of the Social Forum and the challenge it poses to established cultures and practices of politics on the left. It signals a struggle and transition but the outcomes are not yet clear and are certainly not pre-ordained.

The tensions that we observed in Quebec between 2001 and 2007 are not unique and illustrate those that occurred in the Global justice movement. As Hélène Duriez notes (2004: 166), the Genoa counter-summit in July 2001 and the tragic death of activist Carlo Giuliani had crystallized a cleavage in the movement. Polarized around the question of violence as a valuable tactic, this conflict is not just about action modality, but also about organizational modality, discourses and beliefs.

We begin by looking back, to the emergence of the alter-globalization movement in Quebec in the late 1990s. We then turn to the World Social Forum and its influence and expressions in Quebec, along with those of the Intercontinental Youth Camp. Following that we discuss the process of organizing the Quebec Social Forum and its culmination in the events of August 23-26 before offering our conclusion.

We have based our narrative and analysis on the findings of several empirical studies undertaken by each of us separately over the last five years. Our research activities have included documentary and discursive analysis of about thirty key actors or organizations involved, directly or indirectly, in producing the QSF and include their histories of engagement in the 1990s with the problematic of globalization. In the immediate lead-up to the QSF event in August 2007 we attended and observed the majority of preparatory meetings , analyzed the minutes of them all, and interviewed members of the Secretariat of the QSF and representatives of other key organizations: the main women's movement federation, the Fédération des femmes du Québec 
(FFQ) and the main labor union federation, the Confédération des syndicats nationaux (CSN), as well as the main union federation who chose not to formally participate, la Fédération des travailleurs et travailleuses du Québec (FTQ). We also interviewed two participants from earlier Social Forum organizing initiatives. Additionally, we were participant-observers at the QSF event. Finally, we reviewed all available written documentation.

Our analysis is rooted in three main convictions: place matters; history matters; and power matters. Because social forums take place in specific geographical contexts, they are embedded in histories of mobilization and trajectories of activism of the place that influence their form and content. Social forums are not "spontaneous" events but the results of local past experiences with the World Social Forum process combined with specific histories of local struggles (de Sousa Santos 2002). Appreciating the historical moment in which the events occur is crucial in understanding the dynamics among local actors and their role in determining the shape of the resulting event (Agrikoliansky and Sommier 2005; Keating and della Porta 2008). Accordingly, we are attentive to the power dynamics that were expressed during the preparation of the QSF. The analyses that we developed here are based on the narratives of some actors involved in the process, especially youth activists who are not affiliated with specific organizations. These actors are sometimes considered to be marginal to the Quebec scene, because they do not have as many resources as well-established organizations, because they are less numerous in terms of membership -in fact, they do not have a membership- and because they employ different discourses often described as "radical" by the media. We believe that the tensions resulting from the co-presence of two ways of thinking and acting "alternatively" (or for another world) has nothing to do with that their "objective weight" and is of great interest from the point of view of the analysis.

\section{ON THE 'FIELD OF GLOBAL PROTEST’: THE ALTER-GLOBALIZATION MOVEMENT IN QUEBEC}

Relative to the appearance of the anti-free trade movement in Canada, which had its roots in the mid-1980s and the broad support it had achieved by the time of the 1988 federal election, mobilization against neoliberal globalization did not manifest itself in Quebec until the mid-1990s (Duchastel 2003). For purposes of situating the QSF in this history, several distinct threads and moments must be distinguished. The first is the process of trans-nationalization of social movements in Quebec.

The women's movement under its umbrella organization, the Fédération des Femmes $d u$ Québec (FFQ), has been one of the main movements responding to conditions of neoliberal restructuring but also to the globalization of feminism and the trans-nationalization of feminist solidarities that had been fostered through United Nations processes since the 1970s. In the mid1990s, the FFQ organized a ten-day march of thousands of women against poverty, for bread and roses. La marche du pain et des roses was a phenomenal success in terms of mass mobilization, public sympathy, international feminist solidarity and concrete policy gains. The Quebec women's march gave birth to a world-wide mobilization, the World March of Women (WMW) in 2000 (Giraud 2001). This initiative of the Quebec women's movement attracted six thousand women groups (but also unions and political parties) from 163 countries which organized local, national and global marches against poverty and violence against women during the year 2000 . 


\section{JOURNAL OF WORLD-SYSTEMS RESEARCH}

This network, which is still alive and active, is one of the most important global feminist mobilizations and a key player at the World Social Forum. In its formation, the WMW preceded both watershed events of the anti-globalization movement, the shut-down of the World Trade Organization in Seattle and the inaugural World Social Forum in 2001. One of the characteristics of Quebec social movement history regarding alter-globalization is the central role women's movements played in the mobilization.

Along with women's groups, unions were the first to start the fight against globalization, through the protest against free-trade. In Quebec, protests against free-trade began as early as 1986, shortly before the adoption of the first free-trade agreement with the US. But, the Coalition québécoise d'opposition au libre-échange, composed mainly of unions, did not have much success at the national level before the mid-1990s (Brunelle and Deblock 2000). Confronted with a consensus of the elite on the subject of free-trade, and with an absence of clear allies on the political Left, the coalition developed differently from its Canadian counterpart (the Action Canada Network), which was formed mainly around the left nationalist movement. The Quebec coalition became the Réseau québécois sur l'intégration continentale (RQIC) in 1994 and would become an active partner of Common Frontiers Canada and an active member of the Hemispheric Social Alliance, officially founded in 1999 (Brunelle and Deblock 2000).

Despite the earlier feminist-led mass mobilization in Quebec, its internationalization through the late 1990s as the World March of Women, and its clearly anti-neoliberal position, and despite the earlier Quebec unions' coalition, the 'alter-globalization' movement in Quebec is usually dated from the anti-MAI mobilization of 1998. It was at this point in time, that several new social actors emerged that were specifically oriented towards the fight against globalization (or for a different form of globalization) (Lemire 2003).

The mid-to-late 1990s had seen the emergence of radicalized student and anti-poverty movements in Quebec. CANEVAS, le Comité action non-violent, coalesced in 1996 advocating non-violent direct action to resist corporate globalization. In May 1998, it came to international attention as part of the world-wide movement against the Multilateral Agreement on Investment when activists shut down a Montreal hotel where the agreement was being discussed. This action gave the group its permanent name, salAMI, meaning "dirty MAI” in French.

This mobilization was a turning point for many Quebec activists. Between it and the watershed events of April 2001 in Quebec City-the mass protests against the Free Trade Agreement of the Americas-virtually all of Quebec's social movements had entered "the field of global protest" (Dufour 2006). ${ }^{2}$ The anti-MAI mobilizations signaled a change in the political terrain: a growing awareness of the negative effects of globalization, a break with nationalist political elites who had favored greater free trade and economic integration with the US, and a willingness to consider more militant forms of protest. The period was marked by the appearance of new actors, especially young people, new modes of organization, and codes of solidarity. The

${ }^{2}$ Dufour (2006: 319) demonstrates that a "field of global protest" was constructed in Quebec wherein (1) there is a shift in the "privileged mode of belonging to a space" defined territorially and or through networks of social actors; (2) the progressive inclusion of the 'global' in actors' awareness of being situated in a global context, of the interdependence of different scales of social life, and their growing adoption of transnational strategies; (3) the axes which structure the field changed: less around the nation and more around left-right cleavage; (4) state-society relations created specific constraints and opportunities. 
new activism in some Quebec student and anti-poverty movements was characterized by the increased use of direct action, affinity group organizing, use of spokes-councils, street theatre, popular education and an eschewing of both lobbying and reliance on major media (Conway 2003).

In the aftermath of the successful use of mass non-violent direct action in shutting down the World Trade Organization talks in Seattle in November 1999, the new activist currents grew in size and influence across North America. They posed major challenges to established ways of doing things among the more institutionalized centers of power in the movement: in Quebec, the major labor unions, the FFQ, and large NGOs. These conflicts came to a head in April 2001, at mass protests around the Summit of the Americas in Quebec City against the proposed Free Trade Agreement of the Americas (FTAA), and particularly in the debate over "diversity of tactics.”

Even if most of the organizations involved in the counter-summit were against the FTAA, some key organizations, traditional allies of the governing Parti Québecois on the national question, wanted to keep the demonstrations under their control and minimize embarrassment to the Quebec government. A significant and growing number of other groups were aligned in planning multiple forms of non-violent direct action, including civil disobedience, to discredit the leaders' summit, to demonstrate their deep and principled opposition to the FTAA, and to demand that the government release copies of the agreement. All of these groups were broadly aligned, even as they pursued different tactics. Some key organizations like the FFQ straddled both positions and individuals from all these protesting organizations could be found in the range of spaces and approaches that constituted the field of protest in Quebec City in April 2001. ${ }^{3}$

The Quebec People's Summit mobilizations involved all central actors in Quebec (unions, student federations, women groups, anti-poverty groups, environmentalists) and the RQIC was the "maestro" of the organizational aspect of the event, able to mobilize affiliated activists. For those actors, popular education, workshops and street protests (but controlled ones) were the preferred tools. During workshops the level of cooperation and collaboration among actors, including the less formal ones, was very high. The more profound and significant political divide was that over the 'diversity of tactics' which manifested itself most concretely as the main tension between these groups and the CLAC (Convergence des luttes anti-capitalisteConvergence of Anti-capitalist struggles), including the many thousands of young people who were sympathetic to the latter. A multiplicity of actors and practices can be identified with the diversity of tactics position as well, including many diverse anarchist groupings and practices associated with the Black Bloc (Dupuis-Déri 2003). Broadly understood, respect for 'diversity of tactics' implied both an escalation and a diversification of tactics beyond both the routines of lobbying and of legal, stage-managed demonstrations and an ethic of respect for the tactical choices of other activists. This involved an explicit agreement NOT to publicly denounce the tactics of other activists - even those with which you disagreed.

Although for some, embracing diversity of tactics was part and parcel of their antiauthoritarian ideological commitment, many others were driven by a more diffuse sense of mounting social and ecological crises and political urgency. This coupled with a profound alienation from established channels of political representation, led proponents of diversity of tactics to turn to tools of popular education, cultural work, and grassroots community

\footnotetext{
${ }^{3}$ See Dufour 2007 and Conway 2003 for somewhat diverging readings of the cleavages.
} 


\section{JOURNAL OF WORLD-SYSTEMS RESEARCH}

organizing - not just to the highly confrontational forms of direct action as was often assumed. However, proponents also argued for a return to more militant and confrontational tactics, including direct action and civil disobedience. In the name of both escalation and diversity, they defended 'property destruction,' from posting stickers, spray painting, and guerrilla murals to window smashing and defacing of signs. It was this last aspect, coupled with CLAC's refusal to negotiate the boundaries of acceptable tactics, which constituted the line in the sand between it and the other groups.

Organizing within a framework of "respect for diversity of tactics" was embedded in a further commitment to "affinity groups" as the unit of organizing and to democratic decisionmaking in which small autonomous groups decided on the nature of their participation in a direct action and organized independently of any centralized movement authority. This often implied a repudiation of representative forms of democracy, including institutions of the liberal democratic state and of labor unions and more bureaucratized movement organizations. By the time of the demonstrations in Quebec City, those advocating diversity of tactics, most prominently, the CLAC, also repudiated the 'dogmatism of non-violence,' which they understood to be an authoritarian move to a priori render certain forms of political resistance illegitimate. They critiqued a too rigid violence/non-violence binary and rejected the highly ritualized forms of civil disobedience which had protesters passively handing themselves over to the police.

In the lead-up to the Quebec City mobilization, a large pan-Canadian coalition of groups from across the activist spectrum, excluding CLAC, collaborated in organizing the People's Summit and the mass demonstrations. CLAC was excluded (and excluded itself) from the Table de convergence because it was committed to mass direct action within a diversity of tactics framework. SalAMI participated in the Table and organized non-violent civil disobedience, so the exclusion of CLAC was presumably not based on their commitment to direct action per se, but on the impasse around establishing agreed-upon tactical boundaries (Bouchard 2001: 4). While the CLAC was explicitly committed to shutting down the Summit, SalAMI was oriented to attracting "Monsieur et Madame tout le monde" to Quebec City within an explicit commitment to strategic non-violence (Kruzynski 2002). Even if the CLAC position could be objectively seen as marginal to that of other groups involved in the People's Summit, the tensions around "diversity of tactics" were symptomatic of a deeper disagreement about what the fight should be.

The spectacle of April 2001, the sustained defiance at the fence by thousands of young people, the violence of the police response, the mass labor-led march walking away from a confrontation with police at the fence, and the denunciation of the "violence, ${ }^{4}$ of "anarchists" by major labor and feminist leaders, drove a wedge into the movement (McNally 2001; Starhawk 2002). For multiple reasons, some of them having to do with the post- $9 / 11$ context, these particular debates over tactics and understandings of violence were much less salient by the time of the QSF in 2007. However, a significant underlying tension had not disappeared. In particular,

\footnotetext{
${ }^{4}$ We are marking 'violence' to indicate its' loaded and contested meaning. For some in the context of the 2001 demonstrations, violence was implied in any form of defiance of police, resisting arrest or property destruction. For others, notably those advocating diversity of tactics, it was more narrowly understood to mean harm to persons. See Conway 2003 for more extended discussion.
} 
we see the persistence of a generational divide ${ }^{5}$, specifically around the role and importance of pre-figurative and utopian practices, particularly in terms of individual participation and direct democracy and related to alienation from the established modes of organization and decisionmaking on the left. However, between 2001 and the lead-up to the QSF, this division had transformed somewhat. The terms and tone of the debate had changed to a more conciliatory and less polarized one. In the next section, we show how the earlier debates, which had been articulated by many in 2001 as questions of strategy and tactics, reappeared as conflicting appropriations of the social forum.

\section{THE FORUM AND THE CAMP: ABROAD AND AT HOME}

Ever since its inception in January 2001, the World Social Forum has been a magnet for Quebecbased activists and organizations. Although official numbers do not exist, informal polling suggests that the number of Canada-based participants in Porto Alegre rose from about 250 in 2003 to approximately 700 in 2005 (Conway 2006). A survey of the $2005 \mathrm{WSF}$, conducted by the Observatoire des Amériques found that Canadian respondents were more than twice as numerous as US respondents (69 versus 33). Of the Canadians, 30\% were from Quebec. (Brunelle 2006). In 2005, the Quebec delegation was large and included a sizable youth contingent, organized principally by the Montreal-based international development NGO, Alternatives, and funded through the Quebec Ministry of International Relations. Other prominent organizations from Quebec included the World March of Women, which until 2006 was headquartered in Montreal, the CSN, Développement et Paix (Development and Peace), and the networks of "économie solidaire" (solidarity economy). Alternatives and the World March are also members of the International Council of the World Social Forum. Certainly, the enthusiastic political and financial support of major unions, student federations and the Quebec State (through specific programs) helps explain the robustness of the Quebec presence at the World Social Forum, especially in Porto Alegre.

In important ways, the WSF is a product and innovation of the anti-globalization movement, especially as it appeared in the mass demonstrations in the North following the shutdown of the WTO in Seattle (Leite 2005; Whitaker 2007). As a particular political form and mode of organizing, the Social Forum poses challenges to conventional activist practice in both Quebec and English Canada based as it has been on coalitions of formal organizations with formally-delegated representatives, with little room for grassroots participation (Conway 2004: 118-121). Access to international fora had previously been the exclusive business of NGO personnel or national social movement leaders. In the WSF, any group, no matter how small or informal, that supports the WSF charter is welcome to attend and organize its own events as part of the WSF program. Any person, regardless of affiliation, can attend the Forum. The agenda of the Forum is amazingly open, with little filtering of political opinion beyond the required opposition to neo-liberalism. In the WSF, participation is key to the creation of another world, not

\footnotetext{
${ }^{5}$ Talking about a generational divide does not mean that all young activists shared the same point of view but rather that among the activists who share a different conceptions, most of them are young.
} 


\section{JOURNAL OF WORLD-SYSTEMS RESEARCH}

something to be contained or feared, which is not to say that there have not been debates in the WSF as well about optimal forms and levels of participation. ${ }^{6}$

The earliest organizational expression of the Social Forum in Quebec was the Forum Social Régional de Québec/Chaudière-Appalaches which took place in September 2002 and led to the founding of a permanent network (www.reseauforum.org). The event was the result of collaboration between 20 institutionalized groups working on a wide range of concerns. Although clearly inspired by the WSF in Porto Alegre and sharing its opposition to neoliberal globalization, this event was not a social forum as the term is usually understood. It was centrally organized and structured as a deliberative process to produce a common declaration (Conway 2006). After the event, the declaration was diffused to many progressive groups in the Quebec City region. In December 2002, a "constituent assembly" of about 100 participants voted on an organizational structure and so established a permanent communication and action network called Réseau du Forum Social de Québec Chaudière-Appalaches (Bouchard 2003). By 2007, however, this network was very small with a limited presence in the regionally-based mobilizing toward the QSF (Canet 2007b).

In Porto Alegre in 2003, a meeting of activists from Quebec and English-Speaking Canada discussed the possibility of jointly planning a Canada-Quebec-First Nations Social Forum. The failure of this effort is a complex story we cannot analyze here. What is important to note is that it was an important defeat for the Quebec activists who had been involved, notably those associated with Alternatives (including unions) (Létourneau 2005; Beaudet 2005). Throughout 2004, Alternatives pursued cross-sector discussions toward a Quebec-wide social forum. However, this effort was also frustrated, as the major Quebec unions opted out of the social forum process in favor of prioritizing mobilization against the neoliberal agenda of the Charest government in Quebec (Létourneau 2005; FTQ 2005).

In the lead-up to the 2005 World Social Forum, le Comité de Québec pour le FSM 2005 organized a delegation of more than $600 \mathrm{t}$ to Porto Alegre. In a public conference in Montreal prior to the 2005 WSF, it became clear that organizers were divided about the relationship between organizing Quebec participation in the WSF and organizing a social forum in Quebec, and whether any process of organizing a Quebec Social Forum could proceed without major investment by Quebec's unions (Pelletier 2005). Those who wished to pursue the possibility of organizing a Social Forum in Quebec organized meetings in Porto Alegre where about 150 people struck a committee to initiate a different kind of organizing process than that which had been earlier spear-headed by Alternatives. More than half of those committed to moving forward were young people. Small and medium NGOs as well as a large student delegation participated in this decision (Pelletier 2005). L'Initiative vers un FSQ was founded a couple of months after, during the organization of the second "UQAM Social Forum", in March 2005. As Canet indicates, this association was composed of both delegates from organizations and individual activists involved on their own behalf (Canet 2007b).

After extensive outreach to over 5000 organizations across Quebec, an inaugural meeting took place in November 2005 in Quebec City. A Trois-Rivières "headquarters" was formed

\footnotetext{
${ }^{6}$ This is manifest in ongoing criticism about and debates within the WSF's International Council about its legitimacy, representativeness, and (un)democratic functioning, as well as the challenged to the WSF represented by the culture and practices of the Intercontinental Youth Camp. See Guay, 2005 for more details.
} 
(Collectif Mauricie), which spearheaded the organizing process for a Quebec Social Forum, planned for June 2006 in Trois Rivières. However, two months prior to the event, short of funds and low on registrations, organizers called it off.

More youth-led, this organizing attempt was greatly influenced by the ethos and methodology of the Intercontinental Youth Camp (IYC) that has been organized annually alongside the WSF (Côté and Ruel 2006). Hundreds of Quebec youth participated in the IYC and since 2003 had organized youth camps in Quebec. The youth camps are constituted as autonomous spaces for experimenting with alternative ways of life and are produced by the selforganization and participation of all those who come. They are conceived to be a "laboratory of practices," and emerged as a critique of the World Social Forum, which was perceived by IYC organizers as limited to debating, rather than enacting, alternatives to neo-liberalism (IYC 2003). Making the IYC a lived alternative to neoliberal capitalism meant paying concrete attention to the practices of everyday life involved in constructing the built environment, planning and sharing physical space, the provisioning of food and water, managing waste, promoting ethical exchange and consumption, fostering a safe and respectful environment for all participants, and practicing forms of management and governance based on consensus. The organizing approach rejected hierarchy and encompassed an expectation of participation by all in both decision-making and camp chores. Based on the International Youth Camp's vision, le Campement Jeunesse du Québec - renamed le Campement québécois de la jeunesse a year later - was launched in 2003 (Conway and Morrison 2007).

Committed to consensus decision-making, the Quebec youth camp organizers prioritized participatory debating in their planning process (Perreault 2006). In conceiving a self-managed village of solidarity patterned on the IYC, organizers welcomed people of all ages who were interested in horizontal modes of organizing (Campement Jeunesses du Québec CJQ 2003: 1). The first Camp took place 11-20 August 2003 in a rural area south of Quebec City near StMalachie, Comté de Bellechasse. Despite limited financial resources, the organizers attracted over 200 participants (CQJ 2004a: 1). Further editions of the Campement took place each year, with growing success in terms of the numbers of participants and the scope of issues addressed. In 2007, the Campement autogéré (renamed in April 2007) took place from 19-21 August in Montebello, on the eve of the QSF, during the North American leaders meeting on the Security and Prosperity Partnership (SPP). The campers were at the forefront of the SPP protest.

According to our interviews, the Initiative vers un FSQ was driven by profound divisions among actors about the purpose and goals of a Quebec Social Forum as well as how to organize it (Rodrigue and Eme 2007; Canet 2007b; Roy 2007). On one side were a group of young Montreal-based activists, inspired by the Campement experiences, oriented to individuals' participation and direct democracy rather than to organizational representation in a coalitional structure. They were devoted to the QSF as a process in which individual volunteers directly participate in horizontal and decentralized decision-making practices and to the Social Forum event as a space for showcasing and experimenting with alternatives (Canet 2007a). In their view, a Quebec Social Forum, as both process and event, should include all individuals who were willing to fight for "another globalization", without qualification. On the other side were the Trois-Rivières-based leaders of locally-rooted organizations who were involved in the QSF as part of their jobs and as representatives of their organizations. For them, organizations carried greater political weight, both because of their financial resources and the legitimacy conferred by having broad-based membership. In their view, a Quebec-wide social forum could not be held 


\section{JOURNAL OF WORLD-SYSTEMS RESEARCH}

without the collective social actors traditionally involved in large coalitions in Quebec (Laforest and Philips 2001). These two radically opposed visions had been temporally neutralized by an organizing process that allowed the same weight for "citizens" and organizations (between November 2005 and June 2006), but, in the end did not allow for sufficient convergence of interests and identities and the process was abruptly halted (Rodrigue and Eme 2007; Canet 2007a).

\section{TOWARDS THE QUEBEC SOCIAL FORUM: IS ANOTHER PROCESS POSSIBLE?}

After this failure, the organizing process was re-imagined to allow different compromises and incorporate new players. Instead of a process driven primarily by individual volunteers, the remaining organizers, essentially students involved in the association Alter-UQAM, who had been behind the second and third UQAM social forum and part of the Initiative vers un FSQ, decided to allow organizations to formally participate. They proposed writing a Quebec Social Forum Charter to clarify how the organizing process would work. A newly-constituted Montreal-based organizing group led by those from Alter-UQAM took the lead on the project. The Trois-Rivières collective was dissolved and the Charter adopted through a re-founding assembly in September 2006.

As with the WSF, the QSF Charter imagines the Social Forum as an open space of encounter among diverse social groups who share opposition to neoliberal globalization. It is not constituted as an actor but as a space for reflection, debate, and the formulation of proposals. However, the QSF Charter has several distinguishing characteristics. It addresses "citizens" alongside movements and civil society groups and its imagined geography is that of Quebec- and self-consciously Quebec beyond the metropolis of Montreal, including the "regions"-not to Canada nor to the world. The formulation of a Charter allowed those involved to negotiate about the purpose and goals of the QSF. It was drafted by Raphaël Canet, a veteran of the Trois Rivières initiative and associated with Alter-UQAM, who would become a member of the Secretariat of the project, in collaboration with other Alter-UQÀM activists. ${ }^{7}$ He advocated the participation of individuals, those not acting as delegates of organizations, in the organizing and decision-making process of the QSF in the name of building an inclusive process. However, very rapidly, between September and December 2006, any debate about the vision of the Social Forum both as process and event was overtaken by the exigencies of organizing the event.

The central labor bodies (CSN and FTQ) had long doubted the usefulness of a Quebec Social Forum. In their view, there were already multiple sites at which social organizations converged (e.g., Réseau de Vigilance, a watchdog network formed during the 2003 election to monitor the Charest Liberal government ; the annual Journées d'Alternatives; regular citizens' forums in Montreal). Despite their substantial experience in Porto Alegre, it was not clear to them how a Quebec Social Forum would be different nor what it would add. Nevertheless, during the founding meeting in September 2006, several positions were articulated by participants, drawing clearly on their knowledge and experience in Porto Alegre. Some thought that a QSF would "facilitate breaking free of a strictly local dynamic and allow for some kind of convergence between organizations” (PV 2006). Others imagined the QSF as a place to assemble progressive

\footnotetext{
${ }^{7}$ The QSF Charter is directly inspired by the Saguenay Regional Social Forum held in 2006.
} 
forces in order to develop paths to common action. From this perspective, a QSF would, above all, be "a space for the convergence of struggles." (PV 2006).

According to Canet (2007a), to understand why, in 2007, these powerful groups finally embarked on the process of organizing the Forum one must look to the larger political context in Quebec: the Liberal party was in power and the unions, especially the CSN, were largely denied access to government. It had therefore become more immediately relevant to engage with the social movements in order to build counter-power. For the leadership of the FTQ, building formal relationships with movements remained a bad option because it risked the little access they already had to the corridors of power. Officially, the FTQ was not interested in participating (Gagnon 2007) or organizing the QSF in 2007 although various members and local affiliates attended the event.

In analyzing the minutes of the preparatory meetings, one can see how rapidly the understanding of the QSF as an event rather than a process came to prevail. The discussion was quickly overwhelmed by a managerial logic, dominated by concerns over efficiency and effectiveness in producing the event rather than inclusivity and participation in the process.

The first structural decision was not to give individual participants ("citizens") the right to vote in the General Assembly, which was the decision-making body of the Social Forum. The Assemblies remained open to anyone interested but voting rights were restricted to the three permanent members of the General Secretariat; to the representatives of the five logistical committees, to the representatives of each of eight regionally-based collectives convened for the purpose of mobilizing for the forum, and to representatives of each of the organizations committed to the process (one vote per organization). This arrangement was widely seen as a compromise between a logic of "horizontality," in which all individual participants were accorded the same weight and decision-making proceeded according to consensus, and a coalitional logic which recognized the weight of formal organizations bringing material resources to the process and their accountability to larger constituencies both for the use of resources and direction of the process.

The first General Assembly reflected a greater diversity of participants than subsequent meetings as participation by unaffiliated persons without the right to vote dwindled. Labor organizations (the CSN, affiliates of the FTQ, the Fédération interprofesionnelle de la santé du Québec), women's groups associated with the FFQ, several Quebec student associations, and some large NGOs, notably Alternatives and l'Association québécoise des organismes de cooperation internationale (AQOCI) were particularly prominent in the General Assemblies and dedicated significant financial and human resources to the organizing. However, it is also essential to recognize that a significant number of key players in the organizing effort had a history in the 2005 Initiative pour un FSQ and in Alter-UQAM and brought the autonomist sensibilities of these efforts to bear on the process. They included three spokespersons out of six representing the logistical committees and two out of three permanent members of the General Secretariat. Thus they had significant voting power when voting was employed which, in the end, was rarely. In practice, the process unfolded on a largely consensual basis.

According to our interviews because they did not have comparable organizational weight and power, the Alter-UQAM activists sought to occupy strategic positions in the organizing process, which they were able to do because they carried the enormous workload of the everyday organizing on a largely volunteer basis. Because of their presence and deep involvement, they had the de facto power to make many proposals and decisions between meetings of the general 


\section{JOURNAL OF WORLD-SYSTEMS RESEARCH}

assemblies. Perhaps ironically, given these strategies, they were able to be effective carriers of the vision of the Social Forum as a more open, horizontal, consensual, and participatory process. Despite a structure favoring organizational weight, these activists exerted considerable influence in the daily production of the Forum through their consistent presence and endless work on numerous committees. ${ }^{8}$

In the end, 315 workshops and 150 cultural activities were mounted as part of the QSF according to the principle of auto-gestion, or self-organization. 240 organizations and 30 individuals proposed self-organized activities. The Program Committee had determined eight themes and three transversal axes where a diverse array of discussions were grouped to facilitate convergence among them. The axes were: Societal Projects for Tomorrow's Quebec; Resistance and Alternatives to Neo-liberalism: Local and Global; and Feminist Agendas/Issues and Strategies. Despite being structured by the themes and axes, the program of activities expressed a wide range of diverse content. ${ }^{9}$

Nevertheless, organizers noted some worrying absences: discussion of more specifically localized or regionalized issues, the question of war, the relationship between a culture of consumption and alternative culture; aboriginal peoples; and any consideration of social movements in Canada (PV 2007a). People of color and immigrant communities were largely absent from the organizing process and were only about five per cent of attendees at the event. No preparatory process had targeted them specifically. Issues of racism were virtually absent from the program and the event although there was some attention to questions of migration and rights of refugees. These absences were pervasive even as the themes explicitly invited attention to them, in some terms at least. The themes were: (1) human rights and the struggle for equality: rights of peoples and diverse identities; (2) Environment and ecology; (3) public services and social programs: struggles against privatization of the common good; (4) the world of work, labor struggles and the economy of solidarity; (5) arts, culture and pluralism of communications; (6) citizen participation, democracy and popular power: rethinking the political; (7) solidarity and peace: against imperialism and war; (8) spirituality, ethics and religions. Themes five through eight were least addressed in workshops (PV 2007a). Beyond the absences, it is important to recognize the impressive participation of women, who constituted about 60 percent of attendees, and the permeation of feminist concerns in the naming of the themes and transversal axes of the Forum and in numerous self-organized activities. Women were prominent as speakers in the large-scale, centrally-organized events and feminist perspectives were reflected in the documents and statements of the QSF. All were attributable to the strong and consistent organizing and mobilizing efforts of the FFQ (Burrow 2007).

According to Canet (2007b), an important and original contribution of the QSF lay in organizing the program into two dimensions: the first promoting the classic form of dialogue and debate in diverse formats and the second promoting a great array of spaces for cultural and artistic expression (a film festival, displays of visual and performing arts, music, and circus). The opening ceremonies of the QSF, a multi-disciplinary spectacular cultural fest, took place in the

${ }^{8}$ It is interesting to note that at the end, unions contributed for $11 \%$ of the total income of the QSF, registrations 18\%. (Bilan organisationnel du FSQ, 2007: 47).

${ }^{9}$ The themes and axes were not really prescriptive and were used as a way or "putting some order" in the creative disorder the amount of proposals has created, even if they were named before proposals for the self-organized activities has been received. No proposal was rejected. 
middle of downtown Montreal in the Parc Émile-Gamelin, the site of the Forum's cultural program adjacent to UQAM where the workshops took place.

The Écofest collective facilitated a full schedule of activities dedicated to promoting practices of "alternative everyday, ecological and sane consumption." Its program incorporated local artists, multiple activities and performances. More than 2000 people frequented the space daily during the Forum. In collaboration with Moisson Montréal and Poubelle Anonyme, the team of L'être Terre served 1500 free meals per day from left-over food. Access to the park's activities was open to the public and organizers reported that people living in the neighborhood were delighted by the initiative and frequented the space during the days of the Social Forum. Those who participated in the cultural events in the park were, on the whole, younger than those who participated in the workshops inside UQAM. According to the survey previously cited, the average age of respondents was 42-43 years (Bilan organisationnel du FSQ 2007: 49), but it is possible that the small survey sample underestimated youth participation. On August 26, the last day of the forum, an Assembly of Social Movements took place which issued a statement of solidarity produced and signed by a majority of the organizations which had been involved in the organizing. The closing event was a march of about 1000 people (Colbert 2007).

\section{CONCLUSION}

Between the 2001 Quebec Summit of the Americas and the 2007 QSF, the political context had changed. In April 2001, the death of an alter-activist in Genoa and the events of September $11^{\text {th }}$ were not yet tragedies. The issue of violence and violent tactics was openly discussed and a significant number of activists were relatively tolerant of a "diversity of tactics". In 2007 the global social justice movement had become more institutionalized or, at least, more "routinized", through social forum processes. Counter-summits have been de-emphasized in favor of more activities where concrete alternatives proposals are worked on. In this new context, violence is no longer a legitimate subject of debate. The World social forum Charter clearly excludes strategies of violence. The "alter-globalization" label has been imposed. Nevertheless, tensions inside the movement remain but are differently expressed. Today in Quebec, these tensions are driven by youth activists, inspired by the "youth camp culture." In 2001, these young activists were just beginning their involvement. Some were participating in their first big demonstration while others were just spectators but questioned the tensions around a "diversity of tactics" and for the most part, were too young to be concerned. Between 2001 and 2007 events the people involved are different, but the tensions involve the same dynamic of confrontation between two political cultures. The continuity between the two periods is not a material continuity (of activists or organizations) but a symbolic and substantive one.

In an interview preceding the QSF, a representative of the Féderation des Femmes du Québec (FFQ), Nancy Burrows (2007), predicted that the Forum would reflect the state of social movements in Quebec, both their strengths and weaknesses, no more-no less. It will be the fruition of their capacity to mobilize, their collective organizing means and resources, and their ability to work effectively in coalitions. It would also reflect the particular strength of the women's movement in Quebec society and in relation to other movements and, particularly, the organizational vitality and influence of the FFQ. Burrows noted the absence of immigrant groups from the organizing process. After the event, the representative of the CSN said that the Forum 


\section{JOURNAL OF WORLD-SYSTEMS RESEARCH}

also showed the current weaknesses, notably the strategic divergence between key organizations in the labor movement which prevented a strong labor program at the Social Forum, even though people affiliated with various unions participated in the event. We also noted the virtual absence of Aboriginal people both from the organizing and the event, notwithstanding the fact that the Assembly of First Nations had formally joined the QSF early on.

If we follow Burrow's understanding of the QSF, it could not be different from the struggles and power relations that characterize the current dynamics among the groups that constituted the Forum. The Forum as an event therefore represented weak potential for social transformation, reproducing social relations of domination and exclusion within the progressive milieu itself. While this reading captures certain features of the QSF, it ignores others.

The survey conducted by the Secretariat of the QSF (407 respondents), indicates that of the attendees affiliated with organizations, most came from community organizations and NGOs (20\%) and political parties (20\%) (Bilan organisationnel du FSQ 2007: 49). Among the attendees who were registered, 40\% reported being unaffiliated (PV 2007a; Bilan Organisationnel du FSQ 2007:49). What does this signify about the character of engaged civil society in Quebec and about the place of the labor movement? What does it say about the Social Forum as a particular political form and culture of politics? And furthermore, what do the persistent conflicting views of the Social Forum, manifested throughout the organizing process, the event, and the roundtable signify?

In our view, the Social Forum is a new political praxis and form. Although variable across place and scale, its technology of open space is now widely understood and appreciated. Both Letourneau and Canet see the Social Forum as a space for free association, not as an actor that issues declarations or embarks on campaigns. However, after that basic recognition, they diverge significantly. Canet, Alter-UQAM and the youth associated with the Campement see in the Forum a space of experimentation, to generate alternative ways of life in daily practice, in which all people, regardless of affiliation or lack thereof, have a right and responsibility to participate. In organizing the Forum, they ensured the prominence of cultural and artistic expression and space for enacting everyday practices of alternative ways of life, such as providing free meals from left-over food throughout the Forum. For them, the Forum is valuable in and of itself for what it promotes and allows and for what it may generate.

Letourneau, the CSN, and other established, institutionalized centers of the movement like the FFQ and progressive NGOs like Alternatives see the Forum as a potential site for the convergence of struggles. For them, the Forum is a means to an end and their commitment to it is more instrumental and conjunctural. For them the value of the QSF will be reflected in future collective mobilizations that were enabled through the event. Hence, they were somewhat disappointed that the Social Movements Assembly did not produce a stronger call for a common action (Appel solidaire des mouvements sociaux 2007; see the political assessment of the QSF PV 2007b). Similarly, in QSF meetings following the event, these entities resisted endorsing a second QSF in favor of mobilizing around the WSF's globally-coordinated activities on January 26, 2008.

For the autonomist youth, the organizing process and the event represent a seamless whole. Both should be pre-figurative of the alternative world that is in the process of being constructed. Hence, the organizing process itself is a key arena of contestation. For large organizations, the process is merely a means to an end. What is important is that it be efficient and efficacious in producing the event, be accountable to those who are financing it and are the 
legitimate representatives of progressive civil society in Quebec by virtue of their mass membership and internal structures of democratic decision-making. For the young people, their sense of accountability is different. They went to Porto Alegre, were transformed by the Youth Camp and felt an acute responsibility to bring it home to Quebec and root alter-globalization in quotidian practices, if only for a few days a year (Pelletier 2005). Hence, they want a second QSF held it in a location that would allow for a camp and for the orientations that the camp represents.

It is the tension between these fundamentally different visions of what the Social Forum, as both process and event, is, or should be, that operated as a motor of creativity and social experimentation. The innovative organizational architecture of the QSF, as the product of multiple compromises, is the direct result of this tension. In the practice of producing the Social Forum, these diverse actors were also creating new ways of being collectively together.

de Sousa Santos (2002) refers to these tensions as the different temporalities of struggle that co-exist in the social forum: one driven by a sense of immediate urgency and the exigencies of struggle whose terms are already set; the other by the vision of different possible futures, beyond the terms of the present, which can be, and are being, constructed in the free spaces of the present, the blueprint for which does not exist. Underpinning these different political ethos are quite different sensibilities about democracy: on the one hand, for the young autonomists, the ethical responsibility of each person to engage in the construction of alternative futures and the rights conferred through participation; on the other, for the CSN and the FFQ, the power and legitimacy conferred by mass organization, the necessity and desirability of formal, designated and accountable leaders, and their (putative) capacity to represent and mobilize a constituency beyond themselves. The social forum has allowed these differences to become politicized without automatically becoming polarized. Santos attributes to the social forum this capacity of creating a space and a culture of politics that allows for "depolarized pluralities” (2006: 166). We think this helps account for the differences between 2001 and 2007 in Quebec, between the polarization of the anti-FTAA demonstrations and the creative tension, both conflictual and collaborative, of the Quebec Social Forum process.

The QSF surely was and remains a reflection of the social forces of the place, their capacities and limitations in any given moment, as Burrows suggest. However, we have argued that the divisions apparent in the QSF are more than simply conjunctural. They signal a more profound transition underway in political life in Quebec and beyond, to which the social forum phenomenon itself testifies and is a response.

\section{REFERENCES}

Agrikoliansky, Éric and Isabelle Sommier (dir.) 2005. Radiographie du Mouvement Altermondialiste. Le Second Forum Social Européen. Paris: La Dispute.

Appel Solidaire des Mouvements Sociaux. 2007. Unies pour l'avenir du Québec et du Monde. Retrieved October 30, 2007 (http://www.er.uqam.ca/nobel/social/2007/m-moires-dufsq/m-moires-du-fsq-3.html).

Bilan Organisationnel du Forum Social Québécois. 2007. Secretariat du FSQ. Available online: http://www.er.uqam.ca/nobel/social/2007/accueil/m-moires-du-fsq.html

Bouchard, Sebastien. 2001. "La Victoire de la Bataille de Quebec: Bilan et Perspectives". Unpublished paper. 
Brunelle, Dorval and Christian Deblock. 2000. "Les Mouvements d'Opposition au LibreEchangisme dans les Amériques et la Constitution d'une Alliance Sociale Continentale.” Nouvelles Pratiques Socials 13:131-147.

Brunelle, Dorval. 2006. "Le Forum Social Mondial: Origine et Participants.” La Chronique des Amériques 3:1-10.

Campement Jeunesses du Québec. 2003. “Qu’est-ce que le Campement?” Retrieved on May 26, 2006 (http://www.campementjeunesses.org/?q=node/view/31).

Canet, Raphaël. 2007b. “Enfin un Premier Forum Social au Québec!” Bulletin Oeconomia Humana April: 20-23.

Colbert, Robert. 2007. "Mobilisation de Mouvements Sociaux Internationaux, dont ceux d'Haïti, au Premier Forum Social Québécois”, 26 août 2007. On line http://www.alterpresse.org/spip.php ?article.6347.

Conway, Janet. 2003. "Civil Resistance and the 'Diversity of Tactics' in the Anti-globalization Movement: Problems of Violence, Silence, and Solidarity in Activist Politics.” Osgoode Hall Law Journal 41:506-530.

Conway, Janet. 2004. Identity, Place, Knowledge: Social Movements Contesting Globalization, Halifax: Fernwood Publishing.

Conway, Janet. 2006. "La difusión global del Foro Social Mundial: La política de lugar y escala vista desde Canada," trans. Daina Greene. El Foro Social Mundial: Camino a un mundo nuevo. Ed. Frank Bracho. Caracas: Fondo Editorial Question, 2006, 77-89.

Conway, Janet and Dan Morrison. 2007. "A New Political Generation? New Forms of Youth Engagement in Canada and Beyond.” Pp. 243-264 in Power and Resistance: Critical thinking about Canadian social issues, $4^{\text {th }}$ edition, eds. Wayne Antony and Les Samuelson. Halifax: Fernwood Publishing.

Côté, Simon-Olivier and Manon Ruel. 2006. "La culture organisationnelle vénézuélienne et le Campement intercontinental de la jeunesse”, Journal Alternatives, 24 janvier, 2006, Retrieved October 29, 2007 (www.alternatives.ca/article2327.html)..

de Sousa Santos, Boaventura. 2002. "Le Forum social mondial : vers une mondialisation contrehégémonique.” Pp. 185-204 in Samir Amin et François Houtard (dir.), Mondialisation des Résistances: Etat des Luttes 2002, Paris: l'Harmattan.

de Sousa Santos, Boaventura. 2006. The Rise of the Global Left: The World Social Forum and Beyond. New York: Zed Books.

Duchastel, Jules. 2003. “De libre-échangistes, les Québécois sont-ils devenus antimondialistes?” in Michel Venne (dir.) L'annuaire du Québec 2004. Saint-Laurent: Éditions Fides: 65-75.

Dufour, Pascale. 2006. “ Projet National et Espace de Protestation Mondiale: Des Articulations Distinctes au Québec et au Canada.” Revue Canadienne de Science Politique 39:315342.

Dufour, Pascale. 2007. "Globalisation as a New Political Space: The End of the Quebec-Quebec Debate?” Pp 130-152 in Michael Murphy and Daniel Salée (dir.) The State of the Federation. Quebec and Canada in the New Century: New Dynamics, New Opportunities. Kingston, Montreal: McGill-Queens's University Press.

Dupuis-Déri, Francis. 2003. Les Blacks Bloc: La Liberté et l'Egalité se Manifestent. Montreal: Instinct de Liberté.

Duriez, Hélène. 2004. "Modèles d'Engagement et Logiques de Structuration des Réseaux Locaux de la Gauche Mouvementiste à Lille.” Politix 17:165-199. 
Giraud, Isabelle. 2001. "La Transnationalisation des Solidarités: l’Exemple de la Marche Mondiale des Femmes," Lien Social et Politiques-RIAC 45:145-162.

Guay, Nathalie. 2005. "La Jeunesse dans le Mouvement Altermondialiste: Marginalisation ou Auto-exclusion?” Chroniques des Amériques 14:1-10.

IYC: Intercontinental Youth Camp 2003 Camp Organizing Committee (COA). 2003. "Intercontinental Youth Camp: the Registration is Open until January 10.” Retrieved November 19, 2004 (http://www.forumsocialmundial.org.br/dinamic.php?pagina=juventude_fsm2003).

Keating, Michael and Donatella della Porta (eds). 2008. Approaches and Methodologies in the Social Sciences: A Pluralist Perspective. Cambridge : Cambridge University Press.

Laforest, Rachel and Susan D. Philipps. 2001. "Repenser les Relations entre Gouvernement et Secteur Bénévole. À la Croisée des Chemins au Canada et au Québec.” Politique et Sociétés 20:37-68.

Lemire, Marc. 2003. “Les Mouvements Sociaux face à la Globalisation des Marches.”Pp 277-304 in Québec: État et Société, ed. Alain-G. Gagnon. Montréal: Québec-Amérique.

Leite, José Corrêa. 2005. World Social Forum: Strategies of Resistance. Chicago: Haymarket Books.

McNally, David. 2001. "Mass protests in Quebec City: From Anti-globalization to Anticapitalism.” New Politics 8:76-99.

Starhawk. 2002. Webs of Power: Notes from the Global Uprising. Gabriola Island: New Society Publishers.

Whitaker, Chico. 2007. A New Way of Changing the World. Nairobi: World Council of Churches.

\section{SOURCES}

Beaudet, Pierre. 2005. Director of Alternatives in 2005. Interview. Montreal, December 2005.

Bouchard, Sebastien. 2003. Interview. Porto Alegre, Brazil. January 2003.

Burrow, Nancy. 2007. FFQ representative. Interview. Montreal, 17 August 2007.

Canet, Raphaël. 2007. Permanent of the General Secretary, QSF. Interview. Montreal, June 2007.

FTQ. Fédération des travailleurs et travailleuses du Québec. 2005. Interview with the person in charge of international relations. Montreal, December, 2005.

Gagnon, Denise. 2007. Director of International Solidarity, FTQ, meeting, Montreal. October 2007.

Kruzynski, Anna. 2002. Interview. Toronto.

Létourneau, Jacques. 2005. In charge of the international relations, CSN, Montreal. Interview. December 2005.

Pelletier. 2005. Interview. London, Ontario, June 26, 2005.

Perreault. 2006. Interview. Montreal, May 6, 2006.

PV. 2006. Assemblée de foundation (Foundational meeting). 2006. Field notes available on request.

PV. 2007a. Meeting of the General Assemblies of the QSF. October 20, 2007. Field notes available on request.

PV. 2007b. Meeting of the General Assemblies of the QSF. November 17, 2007. Field notes available on request. 


\section{JOURNAL OF WORLD-SYSTEMS RESEARCH}

Rodrigue, Martin and Valérie Eme. 2007. Founders of the Quebec Youth camp and members of the General Secretary of the FSQ in 2006. Interview. Montreal, June 2007.

Roy, Louis. 2007. CSN representative to the QSF. Interview. Montreal, June 2007. 